\title{
Performance Factors and Sulfur Tolerance of Metal Supported Solid Oxide Fuel Cells with Nanostructured Ni:GDC Infiltrated Anodes
}

\author{
Nielsen, Jimmi; Sudireddy, Bhaskar Reddy; Hagen, Anke; Persson, Åsa Helen
}

Published in:

Journal of the Electrochemical Society

Link to article, DOI:

10.1149/2.1081606jes

Publication date:

2016

Document Version

Publisher's PDF, also known as Version of record

Link back to DTU Orbit

Citation (APA):

Nielsen, J., Sudireddy, B. R., Hagen, A., \& Persson, Å. H. (2016). Performance Factors and Sulfur Tolerance of Metal Supported Solid Oxide Fuel Cells with Nanostructured Ni:GDC Infiltrated Anodes. Journal of the Electrochemical Society, 163(6), F574-F580. https://doi.org/10.1149/2.1081606jes

\section{General rights}

Copyright and moral rights for the publications made accessible in the public portal are retained by the authors and/or other copyright owners and it is a condition of accessing publications that users recognise and abide by the legal requirements associated with these rights.

- Users may download and print one copy of any publication from the public portal for the purpose of private study or research.

- You may not further distribute the material or use it for any profit-making activity or commercial gain

- You may freely distribute the URL identifying the publication in the public portal 


\title{
Performance Factors and Sulfur Tolerance of Metal Supported Solid Oxide Fuel Cells with Nanostructured Ni:GDC Infiltrated Anodes
}

\author{
Jimmi Nielsen, ${ }^{\mathrm{Z}}$ Bhaskar R. Sudireddy, ${ }^{*}$ Anke Hagen, and Åsa H. Persson \\ Department of Energy Conversion and Storage, Technical University of Denmark, 4000 Roskilde, Denmark
}

\begin{abstract}
Two metal supported solid oxide fuel cells (active area $16 \mathrm{~cm}^{2}$ ) with nanostructured Ni:GDC infiltrated anodes, possessing different anode and support microstructures were studied in respect to sulfur tolerance at an operating temperature of $650^{\circ} \mathrm{C}$. The studied MS-SOFCs are based on ferretic stainless steel $(\mathrm{FeCr})$ and showed excellent performance characteristics at $650^{\circ} \mathrm{C}$ with fuel utilization corrected area specific resistances of $0.35 \Omega \mathrm{cm}^{2}$ and $0.7 \Omega \mathrm{cm}^{2}$ respectively. The sulfur tolerance testing was performed by periodic addition of 2,5 , and $10 \mathrm{ppm} \mathrm{H}_{2} \mathrm{~S}$ in hydrogen based fuel under galvanostatic operation at a current load of $0.25 \mathrm{Acm}^{-2}$. The results were compared with literature on the sulfur tolerance of conventional SOFC Ni/YSZ cermet anode. The comparison in terms of absolute cell resistance increase and relative anode polarization resistance increase indicates, that the nanostructured Ni:GDC MS-SOFC based anode is significantly more sulfur tolerant than the conventional Ni/YSZ cermet anode. Furthermore, it was shown that the believed extension of the electrochemical three-phase-boundary reaction zone in the presence of GDC must be very limited and cannot account for the higher sulfur tolerance of GDC modified SOFC anodes.

(c) The Author(s) 2016. Published by ECS. This is an open access article distributed under the terms of the Creative Commons Attribution Non-Commercial No Derivatives 4.0 License (CC BY-NC-ND, http://creativecommons.org/licenses/by-nc-nd/4.0/), which permits non-commercial reuse, distribution, and reproduction in any medium, provided the original work is not changed in any way and is properly cited. For permission for commercial reuse, please email: oa @electrochem.org. [DOI: 10.1149/2.1081606jes] All rights reserved.
\end{abstract}

Manuscript submitted February 12, 2016; revised manuscript received March 10, 2016. Published March 26, 2016.

In recent years, there has been a growing interest in developing metal supported solid oxide fuel cells (MS-SOFCs). MS-SOFCs are interesting as they potentially offer some advantages compared to conventional electrode and electrolyte supported SOFCs, such as low materials cost, better thermal conductivity and ductility of the support. The two later aspects improve the shock resistance and lower internal gradients within the stacks. This enables faster start-up, higher tolerance toward operation under transient conditions and operation at higher fuel utilization.

Today's commercially available and relevant SOFC fuels such as natural gas, diesel and biogas etc. all contain trace amounts of sulfur. Thus, tolerance toward sulfur poisoning is desirable. Ceria and gadolinium doped ceria (GDC) have been reported in the literature to have a beneficial effect on the tolerance toward sulfur poisoning. ${ }^{1-4}$ The ceria can be incorporated as a microstructured Ni:GDC cermet anode, but also as non-percolated nanostructuring via infiltration of isolated ceria and doped ceria particles into the conventional microstructured Ni:YSZ cermet anode. Both approaches have been reported to improve the tolerance toward sulfur poisoning. In the present study we report the performance and sulfur tolerance of MS-SOFCs with two different microstructures of the support and the anode functional layer (AFL). The MS-SOFCs of the present study are based on ferritic stainless steel $(\mathrm{FeCr})$ with an aimed operating temperature of $650^{\circ} \mathrm{C}$. This lower operating temperature compared to electrode and electrolyte supported SOFC $\left(750^{\circ} \mathrm{C}-850^{\circ} \mathrm{C}\right)$ will favor sulfur adsorption and is thus expected to increase the impact of sulfur poisoning. The AFL was infiltrated with Ni-GDC precursor solution and subsequently heat treated resulting in a percolated nanostructured coating of the electrocatalyst.

In the present study we report on the sulfur tolerance of MS-SOFCs with the novel Ni:GDC nanostructured anode and discuss it in relation to performance and in comparison to the conventional SOFC Ni:YSZ cermet anode.

\section{Experimental}

Cell fabrication.- Symmetrical cells consisting of an electrolyte (ScYSZ, i.e. $\mathrm{ZrO}_{2}$ co-doped with $\mathrm{Sc}_{2} \mathrm{O}_{3}$ and $\mathrm{Y}_{2} \mathrm{O}_{3}$ ) sandwiched in between MS-SOFC FeCr/YSZ based Ni:GDC infiltrated AFL anodes

\footnotetext{
*Electrochemical Society Member.
}

zE-mail: jini@dtu.dk were prepared using the similar processing and infiltration route as described in Ref. 5,6.

For full cells, the half-cell (i.e. metal support, anode, electrolyte) processing and infiltration route, described in Refs. 7,8, was also used in this study. The processes involved tape casting of the layers: metalsupport (a ferritic stainless steel alloy), cermet backbone (with 0-50 vol.\% Y-doped doped $\mathrm{ZrO}_{2}$ with respect to metal), and ScYSZ electrolyte, followed by a subsequent co-sintering of these layers in a reducing atmosphere $\left(\mathrm{H}_{2} / \mathrm{Ar}\right)$. The difference in microstructure of the studied cell $\mathrm{A}$ and cell $\mathrm{B}$ is a consequence of exploring different pore former amounts and presence of ceramic sintering hindering additives. The electrocatalytically active phase, comprising a precursor solution of $\mathrm{Ce}_{0.8} \mathrm{Gd}_{0.2} \mathrm{O}_{1.9}$ and $\mathrm{Ni}$ (hereafter referred to as Ni:GDC), was infiltrated as a next step. The infiltration of electrocatalysts followed the same procedure as described elsewhere. ${ }^{5}$ Cells being evaluated for electrochemical performance were deposited with a $\mathrm{Ce}_{0.9} \mathrm{Gd}_{0.1} \mathrm{O}_{1.95}$ inter-diffusion barrier layer on the electrolyte, using the physical vapor deposition technique as described in Ref. 7. Finally, the cathode layer comprising $\left(\mathrm{La}_{0.6} \mathrm{Sr}_{0.4}\right)_{0.99} \mathrm{CoO}_{3-\delta}: \mathrm{Ce}_{0.8} \mathrm{Gd}_{0.2} \mathrm{O}_{1.9}$ (LSC:GDC) and a LSC current collecting layer was applied by screen printing as the last components.

Electrochemical characterization.-The symmetrical cell measurements were performed in specially designed rigs, ${ }^{9}$ which have been constructed to allow for simultaneous testing of four symmetric cells (cell area $6 \times 6 \mathrm{~mm}^{2}$ ) per test run, with fully automated changes of testing conditions, such as temperature, and gas composition. Ptpaste was applied onto the electrodes to form a current collection layer.

The single MS-SOFCs had a $5 \times 5 \mathrm{~cm}^{2}$ cell area with an active area of $16 \mathrm{~cm}^{2}$ (defined by the screen-printed cathode layer). They were tested in an alumina housing used for conventional anode-supported cells. ${ }^{10}$ A coarse meshed Pt net on top of a $1 \mathrm{~mm}$ thick $4 \times 4 \mathrm{~cm}^{2}$ Pt block with gas channels was used as a current collector plate on the anode side. On the cathode side a fine meshed Pt net with a 1 mm thick $4 \times 4 \mathrm{~cm}^{2}$ Pt block with gas channels on top was used as current collector. The cell was sandwiched in between the current collectors with the edges of the cell being sealed with glass bars. On top of this arrangement a weight of $4 \mathrm{~kg}$ was applied. The cells were heated to $800^{\circ} \mathrm{C}$ in the test rig in order to seal the cell and in-situ sinter the cathode before the tests were started. Polarization curves and impedance data were collected in the temperature range 


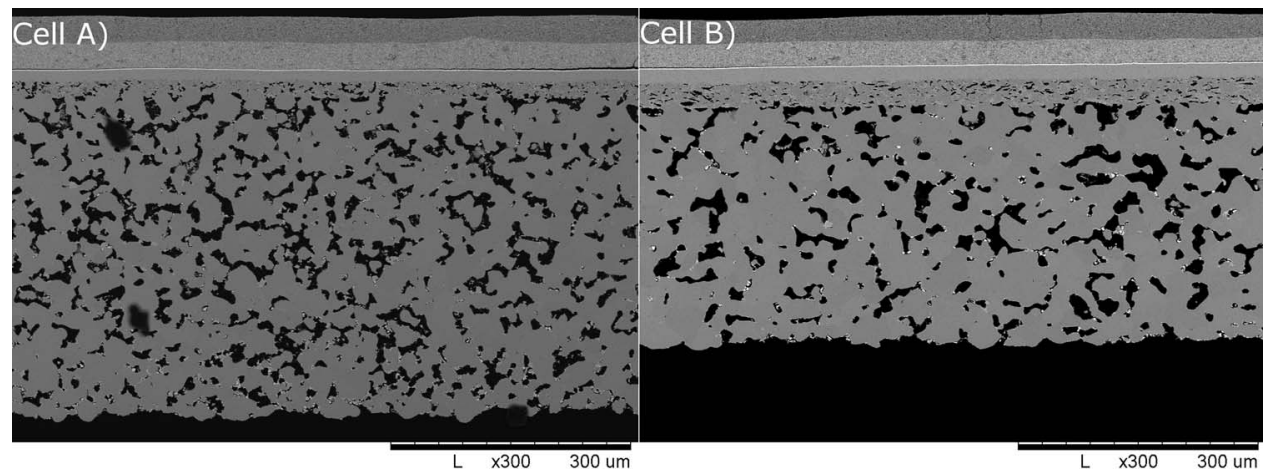

Figure 1. SEM micrographs showing the microstructure of the tested cells. The layers are starting from the top: LSC current collecting layer, LSC:GDC cathode, GDC inter-diffusion barrier layer, ScYSZ electrolyte, anode fuctional layer (AFL), metal support.

of $750-650^{\circ} \mathrm{C}$. Air was used as oxidant with a flow rate of $140 \mathrm{Nl} / \mathrm{h}$, while the fuel was $25 \mathrm{Nl} / \mathrm{h} 4 \%$ bubble flask humidified hydrogen. The Area Specific Resistances (ASRs) within the present paper has been corrected for fuel utilization as outlined in Ref. 10 and is in the following abbreviated $\mathrm{ASR}_{\text {corr }}$. Addition of $\mathrm{H}_{2} \mathrm{~S}$ was performed by diluting a gas mixture consisting of $200 \mathrm{ppm}_{2} \mathrm{~S}$ in $\mathrm{H}_{2}$ with pure $\mathrm{H}_{2}$.

The impedance data were recorded using a Solartron 1260 GainPhase Analyzer (Solartron Instruments, Houston, Texas). The perturbation amplitude was $60 \mathrm{~mA}$ for single cell testing, while it was $40 \mathrm{mV}$ RMS for the symmetrical cell testing. The impedance was recorded in the frequency range $1 \mathrm{MHz}-1 \mathrm{~Hz}$ for symmetrical cells and for single cells the frequency range was $96.850 \mathrm{kHz}-0.096850 \mathrm{~Hz}$.

For visualization at which frequencies changes occur in the impedance spectra during testing, the method "Analysis of Difference in Impedance Spectra" (ADIS) was used. ${ }^{11}$ In the ADIS method the difference between the derivative of the real part of the impedance with respect to frequency is plotted as a function of $\log$ (frequency).

Microstructural characterization.-The microstructure of the various cell samples was investigated using polished cross-sections. The polished cross-sections were prepared by vacuum embedding the samples in Struers epoxy resin (Epofix); ground using $\mathrm{SiC}$ paper; polished using 6,3 and $1 \mathrm{~mm}$ diamond paste, and then carbon coated to eliminate surface charging. Scanning electrotron microscopy (SEM) imaging with backscattered electrons was performed using a Hitachi TM1000 tabletop SEM.

\section{Results and Discussion}

Performance of tested cells.-The microstructures of the tested cells are shown in Figure 1. From the figure it is possible to see that the cell type A has an open microstructure with a support thickness of $400 \mu \mathrm{m}$. This is in contrast to cell type B with a denser microstructure, slightly thicker AFL, but thinner support thickness of $300 \mu \mathrm{m}$. The cells were infiltrated with the exact same infiltration procedure. In respect to the characteristics of this type of electrocatalyst coating it has been shown in previous studies with transmission electron microscopy (TEM) that the Ni particles are nanosized $(5-40 \mathrm{~nm})$, evenly distributed and stabilized within the matrix of GDC. ${ }^{6}$ The resulting performance of the cells at $650^{\circ} \mathrm{C}$ is shown in Figure 2 . The cell type A with an open microstructure performs excellent with a fuel utilization corrected area specific resistance $\mathrm{ASR}_{\text {corr }}=0.35 \Omega \mathrm{cm}^{2}$. This is in fact to our knowledge the best MS-SOFC performance at $650^{\circ} \mathrm{C}$ on single cell level, which is reported in the literature. The performance of cell A is twice as good as cell type B with an $\mathrm{ASR}_{\text {corr }}=0.7 \Omega \mathrm{cm}^{2}$. Previously, we have reported excellent MS-SOFC performance with an ASR $0.3 \Omega \mathrm{cm}^{2}$ on button cell level (active area $0.5 \mathrm{~cm}^{2}$ ). ${ }^{7}$ Testing these cells on a single cell level (active area $16 \mathrm{~cm}^{2}$ ) showed a performance of $\mathrm{ASR}_{\text {corr }} \sim 0.5 \Omega \mathrm{cm}^{2}{ }^{7}$ This may at first sight seem puzzling, but there is one clear difference in the setup for button cell and single cell testing, which is the supply of gas and which affects the performance results. In the button cell setup, the fuel gas flow and oxidant flow is perpendicular to the cell and hence, the gas is directly blown onto/into the porous electrodes of the cell. This is in contrast to single cell testing, where the gas flow is a plug flow geometry with the gas flowing along the cell in gas channels or through a conjugated current collecting mesh. The implication is that the gas exchange between the gas channels and the electrodes are purely diffusion driven. Furthermore, in the button cell setup the cell experiences a uniform gas concentration whereas in the plug flow geometry, the gas concentration varies along the gas channels despite high flow rates are used in cell performance evaluations (low oxygen and fuel utilization $<15 \%$ ). The flow designs in stacks are based on a plug flow geometry and single cell testing therefore mimic to a higher extent the technological relevant situation in a stack. Thus, button cells seem to have a tendency to slightly overestimate the cell performance compared to the one obtainable in stack environment

From the results in this work, shown in Figure 2, it is clear that the porosity seems to have a pronounced effect on the cell performances. There may be a number of reasons for this. Even though the exact same infiltration procedure was applied, it seems that more infiltrate is introduced all the way into the AFLs of the cells with a more open
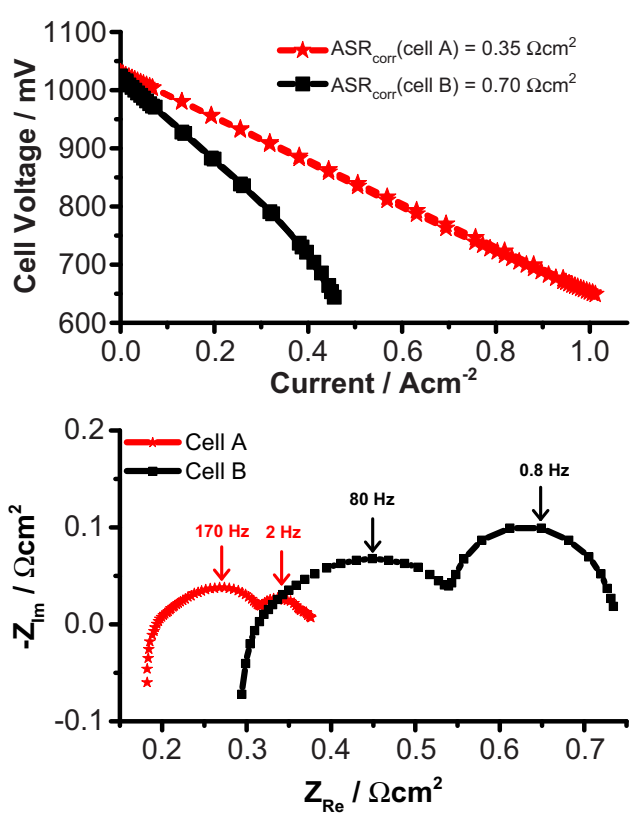

Figure 2. Performance characteristics of studied MS-SOFCs with different microstructures in a fuel atmosphere of $80 \% \mathrm{H}_{2} / 20 \% \mathrm{H}_{2} \mathrm{O}$ with air as oxidant at $650^{\circ} \mathrm{C}$. Top: Current-Voltage characteristics Bottom: Impedance spectra at open circuit conditions. 

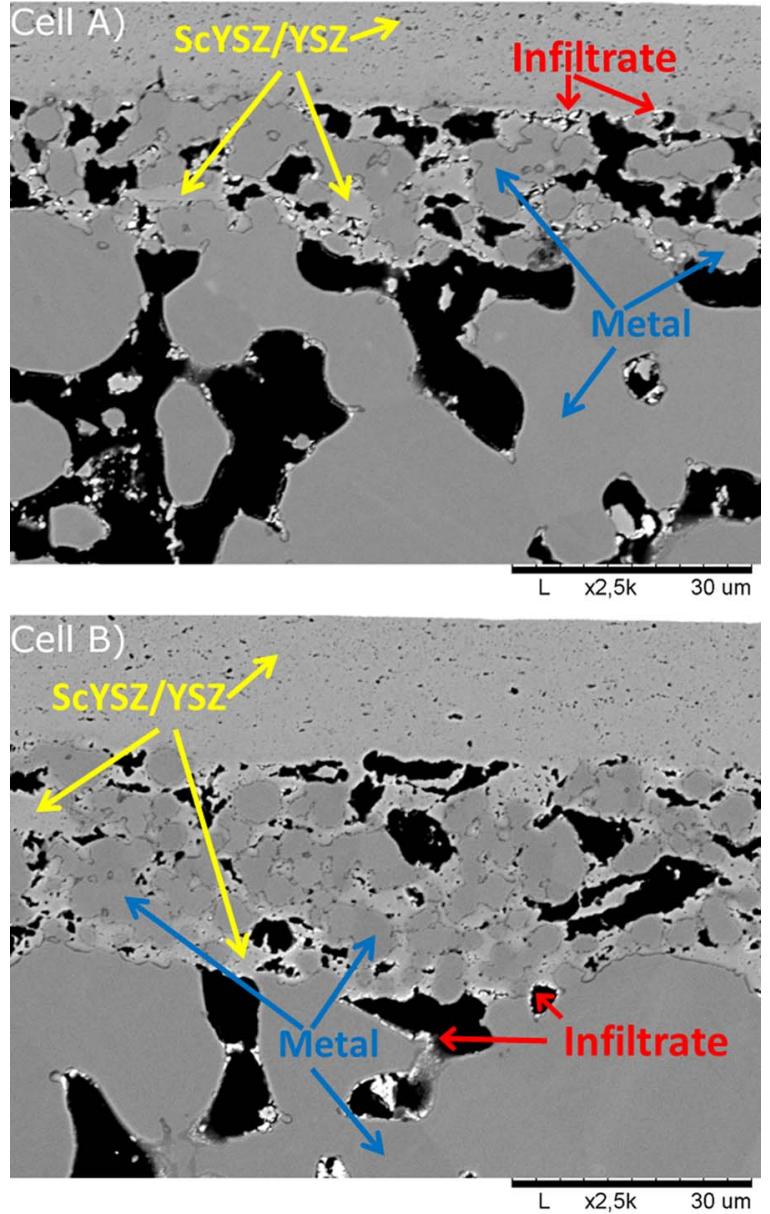

Figure 3. Zoom in on the AFL microstructure of the studied MS-SOFCs presented in Figure 1.

microstructure in both the AFL and the support layer. Indeed, the zoom in on the AFL of the two cells in Figure 3, reveals that larger lumps of infiltrated electrocatalyst (bright spots) is evenly distributed within the AFL and the support for cell A with an open microstructure. This is in contrast to cell B with a denser microstructure. Here it is possible to see that the infiltrate (bright spots) is present and uniformly distributed within the support, but it is absent in the AFL. From the image it is possible to see that the presence of larger lumps of infiltrate (bright spots) stops at the AFL/support interface of cell B. Thus, the AFL of cell B is apparently too dense and as a consequence significant lower amounts of electrocatalyst is deposited in the anode, which is part of the reason for the observed lower performance of cell B.

Furthermore, it is known from X-ray nanotomography 3D reconstructions that the outermost part of the metal support can be somewhat denser for cells prepared by the used fabrication route. ${ }^{12}$ For cells similar to type B in Figure 1 tortuosities around 5 were found along with a relatively low density of percolated pores. For comparison, ASSOFCs with the conventional Ni:YSZ cermet anode have typically a tortuosity of around or slightly below $2 .{ }^{13-15}$ It must be noted that some confusion regarding tortuosity $\tau$ and tortuosity factor $\tau^{2}$ exist within literature as pointed out by Epstein. ${ }^{16}$ That the denser AFL and support layers of cell B significantly affect the gas transport properties is also supported by the relatively large low frequency impedance diffusion/conversion arc $\left(\mathrm{f}_{\text {summit }} \sim 0.8 \mathrm{~Hz}\right.$ ) for cell B in comparison to that of cell A ( $\mathrm{f}_{\text {summit }} \sim 2 \mathrm{~Hz}$ ) as shown in Figure 2. Furthermore, it is also possible that there is a significant difference in the serial resistance $R_{S}$ of the two studied cells, as seen from the impedance spectra in Figure 2. GDC is under reducing conditions an electronic conductor and the deposition of a percolated GDC coating in the AFL will therefore make the whole AFL/electrolyte interface electrochemically active at high frequencies due to the electrochemical double layer capacitance. The difference in deposited Ni:GDC within the AFL for the two cells is presumable the main reason for the observed difference in $R_{s}$.

A way to view and model porous electrode structures is to look at it as an array of columns, which is illustrated in Figure 4. This approach has with success been applied to the present case of a Ni:GDC infiltrated MS-SOFC FeCr based anode. ${ }^{6}$ For mixed ionic electronic conducting (MIEC) porous electrodes there will be some tortuous pathway for electrons and ions through the porous electrode. Taking this tortuous pathway and stretching it out will result in a structure, which as first approximation conveniently can be described as a column. This homogenized way of looking at the MIEC porous electrode as one phase with a given electronic and ionic conductivity can conveniently be described by a transmission line and has proven itself to be highly applicable. Examples include MIEC material or MIEC composite SOFC cathodes, ${ }^{17-19}$ the MIEC Ni:YSZ composite SOFC anode, ${ }^{20,21}$ MIEC infiltration based SOFC anodes ${ }^{6}$ and in general MIEC electrodes. ${ }^{22-24}$

For further details and justification of this type of transmission line modelling approach the reader is referred to the provided references. In this view there are two possible factors, which can affect the performance in the given context. Firstly, a high and fine porosity may
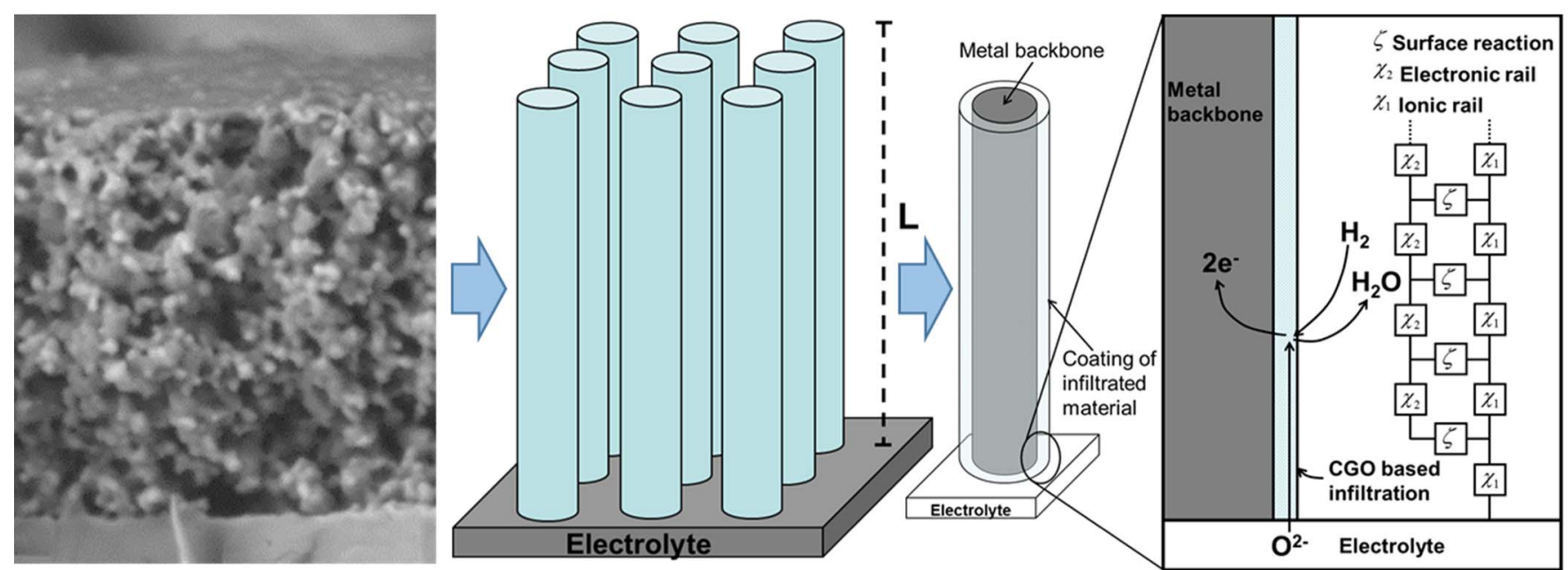

Figure 4. Illustration of modelling the porous MIEC electrode structure as an array of columns. In this particular case it is applied to the present case of a Ni:GDC infiltrated $\mathrm{FeCr} / \mathrm{YSZ}$ based anode. ${ }^{6}$ 


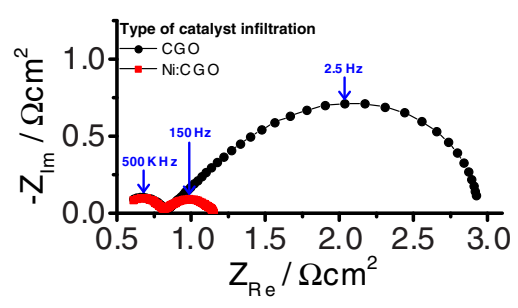

Figure 5. EIS of symmetrical cell tests showing the effect of having $10 \mathrm{wt} \%$ $\mathrm{Ni}$ (with respect to GDC) in the infiltrated catalyst on the polarization resistance $\mathrm{R}_{\mathrm{p}}$. The EIS spectra were recorded in a gas composition of $97 \% \mathrm{H}_{2} / 3 \% \mathrm{H}_{2} \mathrm{O}$ at $650^{\circ} \mathrm{C}$.

be interpreted as a higher density of columns, which corresponds to a larger gas/solid interfacial area of the AFL being electrochemically active (lower $\zeta$ surface reaction impedance). Secondly, if a higher porosity results in more $\mathrm{Ni}$ :GDC material being infiltrated into the AFL layer it would increase the thickness of the coating and lead to an increase in the AFL ionic conductivity as Figure 4 suggests (lower impedance $\chi_{1}$ of electrode ionic conduction). Therefore, from a performance point of view it is beneficial with an open microstructure of the support and the AFL. In general, one would also expect thicker coatings to be more stable in the sense that they are less likely to breakup into non-percolated island like structures. However, from a corrosion durability point of view the situation is different. To minimize corrosion and increase the lifetime of the metal support and metal based AFL, it is desirable to have an as low as possible gas/solid inner surface area. A support with a porosity consisting of fewer but larger pores ensures gas permeability while keeping the gas/solid inner surface area at a minimum. Thus, from the above considerations it is clear that technologically relevant cells will be a trade-off between performance and durability.

The presence of minor amount of nickel $(10 \mathrm{wt} \%)$ in the GDC based infiltrate has a huge impact on the performance. This has already been reported ${ }^{5,6}$ and is illustrated by the symmetrical cell tests in Figure 5 showing a factor 7 decrease of polarization resistance $R_{p}$ in the presence of Ni. From these results it can be concluded that the hydrogen oxidation reaction is predominantly catalyzed by $\mathrm{Ni}$, which is very important to remember, when evaluating the anode sulfur tolerance.

Sulfur tolerance.-The effect of short time addition of varying concentrations of $\mathrm{H}_{2} \mathrm{~S}$ during galvanostatic operation at $0.25 \mathrm{Acm}^{-2}$ of cell A and B are shown in Figure 6. Prior to addition of $\mathrm{H}_{2} \mathrm{~S}$, stable or even slight activation during operation was observed. The effect and characteristics of addition/removal of $\mathrm{H}_{2} \mathrm{~S}$ for the studied MS-SOFC in Figure 6 are similar to what is observed for conventional SOFC Ni:YSZ cermet anodes..$^{25,26}$ Generally, the sulfur effect is a combined passivation and degradation. Upon sulfur addition an immediate drop (passivation) of performance is observed, which conveniently can be referred to as a $1^{\text {st }}$ stage effect. This is followed by a $2^{\text {nd }}$ stage, which consist of a continues stable operation or a continues degradation or a combination hereof. Removal of $\mathrm{H}_{2} \mathrm{~S}$ from the supplied hydrogen fuel gas, results in a full or partly recovery of the cell performance. Thus, the anode nanostructuring and presence of ceria do not alter the apparent sulfur poisoning characteristics on the $\mathrm{Ni}$ catalyst. As was concluded from Figure 5, the hydrogen oxidation reaction is predominantly catalyzed by Ni. However, the presence of ceria or/and doped ceria may reduce the effect of sulfur by acting as e.g. sulfur absorbent as reported in the literature..$^{27,28}$

Initial effect of sulfur.-The impedance prior to any $\mathrm{H}_{2} \mathrm{~S}$ addition and the impedances immediately after the voltage drop upon $\mathrm{H}_{2} \mathrm{~S}$ addition are shown in Figure 7A. The impedance increased as expected with increasing concentration of $\mathrm{H}_{2} \mathrm{~S}$. In Figure 7B, the ADIS visualization of the EIS changes is shown. From the ADIS plot, it is clear that changes occur in the frequency range $100-10 \mathrm{~Hz}$ and around $1 \mathrm{~Hz}$

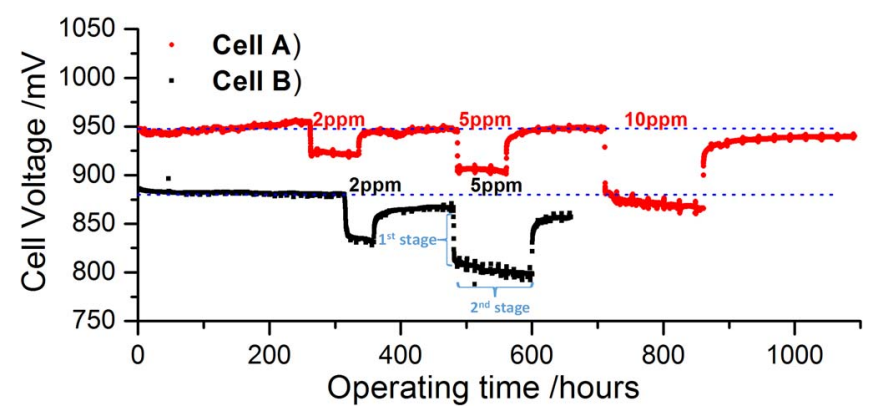

Figure 6. Effect of $\mathrm{H}_{2} \mathrm{~S}$ sulfur poisoning on the MS-SOFCs during constant operation conditions at $650^{\circ} \mathrm{C}$. The cells were in both cases operated with air as oxidant and $4 \%$ humidified hydrogen as fuel at a current load of $0.25 \mathrm{Acm}^{-2}$. The oxygen and fuel utilization were less than $15 \%$.

upon addition and increasing the amount of $\mathrm{H}_{2} \mathrm{~S}$. From symmetrical cell studies on the anode of the present study, it is known, that the anode electrochemical response is located in the frequency range 100-10 $\mathrm{Hz}$, whereas the contribution at approximately $1 \mathrm{~Hz}$ is associated with gas diffusion/conversion..$^{5,6}$ The addition of sulfur poisons the anode, which leads to a change of the current distribution. This can e.g. be monitored by changes in the in-plane voltages of the cell, ${ }^{26}$ where the poisoning initially is envisioned to happen as a moving front from the gas inlet across the cell. The change in current distribution is reflected as a change in the resistance associated with gas diffusion/conversion. The two tests shown in Figure 6 are performed under the same conditions with a current load of $0.25 \mathrm{Acm}^{-2}$. Comparison shows a higher voltage drop upon $\mathrm{H}_{2} \mathrm{~S}$ exposure for cell $\mathrm{B}$ than cell $\mathrm{A}$. The difference in sulfur tolerance can be understood in terms of the difference in the performance of the cells. The presence of a given $\mathrm{H}_{2} \mathrm{~S}$ concentration will result in the Ni catalyst being passivated by adsorbed sulfur. This is similar for the two cells, but the amount of Ni:GDC catalyst in-
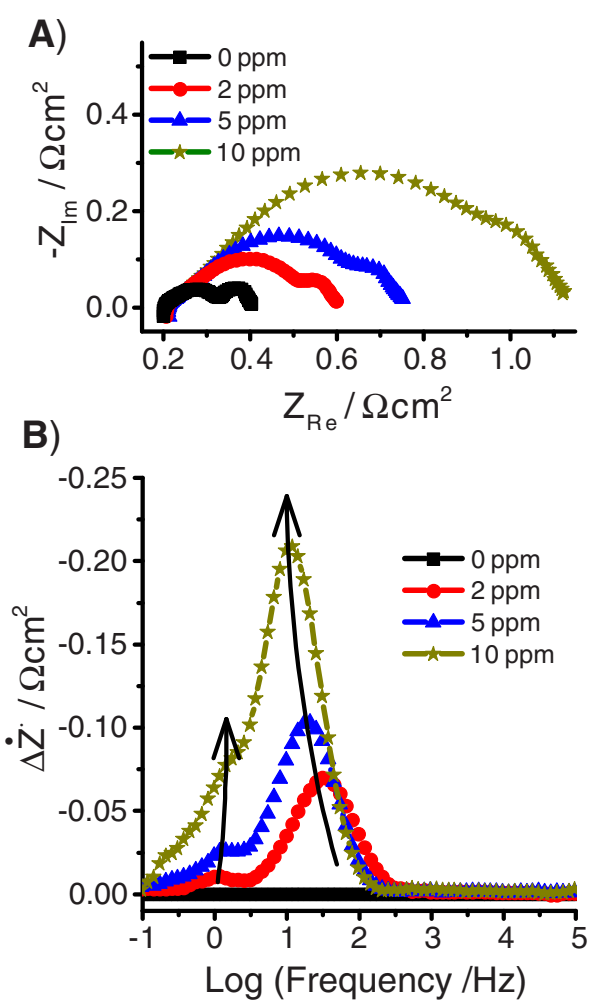

Figure 7. A) The EIS response showing the passivation/degradation of the cells upon addition of $\mathrm{H}_{2} \mathrm{~S}$. B) The ADIS representation of the EIS changes occurring upon $\mathrm{H}_{2} \mathrm{~S}$. 
filtration per volume (density) is different with the best performing cell A having the highest density of Ni:GDC catalyst. Thus, the anode impedance $\zeta$ representing the electrochemical fuel oxidation of the transmission line model in the right part of Figure 4, will increase by a certain percentage at a given sulfur Ni coverage. In previous detailed impedance studies with systematic variations of operation conditions for Ni:GDC and GDC infiltrated MS-SOFC anodes, the homogenized transmission line model in Figure 4 was applied, which nicely illustrated roughly a factor 7 decrease in $\zeta$ and a change in the associated activation energy ${ }^{6}$ upon addition of $\mathrm{Ni}$ to the infiltrate material. Thus, these studies showed that a factor 7 improvement in $\zeta$ resulted in a decrease of the polarization resistance by a factor of roughly 7 . For the present work the electrochemical activity of the $\mathrm{Ni}$ will upon sulfur poisoning decrease by a certain percentage. This is similar for both cell $\mathrm{A}$ and cell $\mathrm{B}$, but as the initial performance is different, the absolute resistance increase will be different for the two cells. This will make well performing cells look more sulfur tolerant at first sight, but this may not necessarily be true. A more detailed analysis is needed. For illustration, the absolute increase of cell resistance as a function of $\mathrm{H}_{2} \mathrm{~S}$ concentration of the present MS-SOFC anode is compared with literature results on AS-SOFCs with the conventional Ni/YSZ cermet anode at different temperatures and current densities in Figure 8. As can be seen from comparison of the $\mathrm{T}=650^{\circ} \mathrm{C}$ results the MS-SOFC anode of the present study seems to be significantly more sulfur tolerant than the Ni/YSZ cermet anode. However, it may simply be due to a better initial performance. For the conventional Ni:YSZ cermet SOFC anode a Temkin-like isotherm has been used for the description of the Ni sulfur surface adsorption. ${ }^{30}$ Using the constants provided, the Temkin-like isotherm can be expressed as:

$$
\theta_{S}=1.45-9.53 \cdot 10^{-5} \cdot T+4.17 \cdot 10^{-5} \cdot T \cdot \ln \left(\frac{p\left(H_{2} S\right)}{p\left(H_{2}\right)}\right)
$$

$\mathrm{T}$ is here the temperature in Kelvin and $\mathrm{p}\left(\mathrm{H}_{2} \mathrm{~S}\right)$ and $\mathrm{p}\left(\mathrm{H}_{2}\right)$ are the partial pressures of the respective gases. Applying the above expression to the conditions of the present study results in the following sulfur coverages $\theta_{\mathrm{s}}=0.86(2 \mathrm{ppm}), \theta_{\mathrm{s}}=0.89(5 \mathrm{ppm}), \theta_{\mathrm{s}}=0.92(10$ ppm). For conventional Ni:YSZ cermet anodes a linear relationship was found between the drop in power output and the sulfur surface coverage calculated using the Temkin isotherm. ${ }^{30,31}$ A few interesting but somewhat peculiar conclusions can be made by inspection of the reported plots. First, it requires quite high sulfur coverages before any effect of sulfur can be observed $\theta_{\mathrm{s}}>0.5$ and secondly the anode will still be very active at $\theta_{\mathrm{s}}=1$. However, it is important to remember, that the Temkin isotherm is not valid for either very low or very high coverages. From Figure 5 the effect of having Ni in the infiltrated catalyst was a factor 7 improvement of the polarization resistance. From

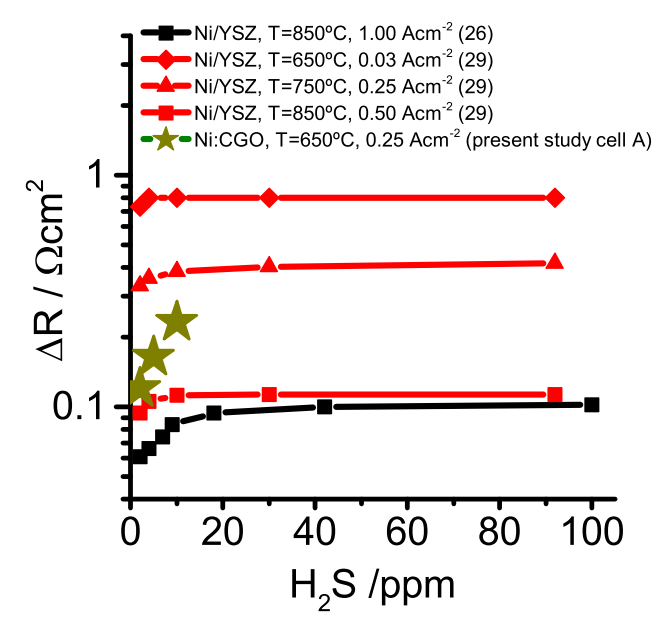

Figure 8. Comparison of the absolute increase of cell resistance upon addition of $\mathrm{H}_{2} \mathrm{~S}$ in hydrogen fuel of AS-SOFCs with the conventional Ni:YSZ cermet anode and the present MS-SOFC Ni:GDC infiltration based anode.

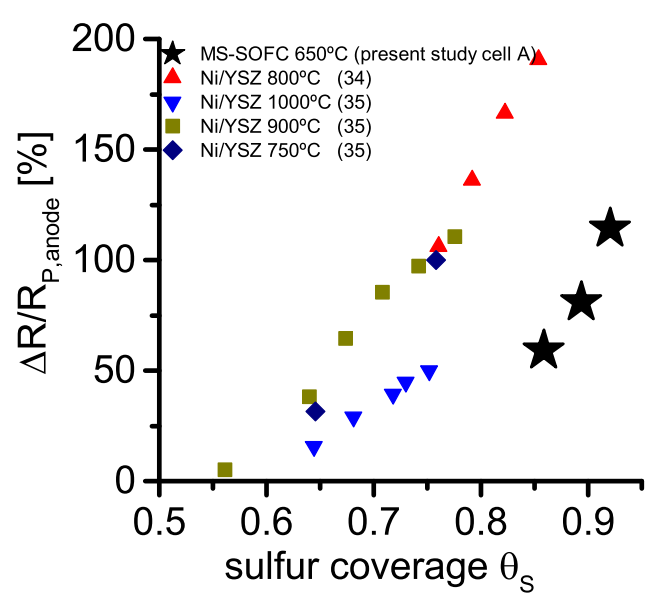

Figure 9. The relative increase of anode polarization resistance Rp as a function of sulfur coverage. The sulfur coverage is calculated using the Temkin-like isotherm given by Eq. 1 .

deconvolution of MS-SOFC impedance spectra by combined distribution of relaxation times (DRT) and equivalent circuit analysis on cells having a similar open microstructure as cell A of the present study, the electrochemical anode resistance was estimated to be $171.2 \mathrm{~m} \Omega \mathrm{cm}^{2} .{ }^{32}$ Similarly, the anode gas diffusion/conversion was estimated to be 31.9 $\mathrm{m} \Omega \mathrm{cm}^{2}$ at a gas composition of $40 \% \mathrm{H}_{2} / 60 \% \mathrm{H}_{2} \mathrm{O}$. Using these values, the relative increase of anode resistance is plotted as a function of sulfur coverage in Figure 9. The $\mathrm{H}_{2} \mathrm{O}$ content of used fuel composition of the present study is significantly lower $(4-15 \%)$ than in Ref. 32, which gives a higher gas diffusion/conversion resistance and would in fact lead to an even higher tolerance than depicted in Figure 9. Most studies within the literature report the effect of sulfur poisoning as a voltage drop or performance drop of the whole fuel cell. This makes comparison difficult as the loss contributions from the different cell components differ and quite often the studied temperature is also not the same. From different reviews consensus seems to exist on the recommendation of using the relative impact on anode polarization resistance as a suitable measure for the SOFC tolerance toward sulfur $\left(\mathrm{H}_{2} \mathrm{~S}\right)$ poisoning. ${ }^{25,27,33}$ Nonetheless, very few studies have actually estimated the cell anode polarization resistance. Only, a very limited number of 3-electrode setup studies exist, which have investigated the effect of sulfur poisoning on SOFC anodes. ${ }^{34,35}$ From the impedance spectra of 3-electrode measurements it is straight forward to estimate the Ni:YSZ anode polarization resistance. However, since anode supported SOFC (AS-SOFC) are aimed at an operating temperature of $750-850^{\circ} \mathrm{C}$, these studies have been performed at higher temperatures than the $650^{\circ} \mathrm{C}$ of the present MS-SOFC study. A way to compare the present results with other studies at different conditions is to use the Temkin-like isotherm of Eq. 1 and do a conversion to a corresponding sulfur Ni surface coverage. This is what has been done and is shown in Figure 9. Firstly, a linear behavior is seen for each plotted data series. Secondly, the Ni/YSZ anode data series at $1000^{\circ} \mathrm{C}$ sticks somewhat out compared to the linear trend of the remaining $\mathrm{Ni} / Y S Z$ data. Nonetheless, there seems to be a clear indication that the nanostructured Ni:GDC anode is more tolerant than the conventional Ni:YSZ SOFC anode, when one extrapolates to similar sulfur Ni coverage for the two types of anodes. From Figure 9, it is seen that the approximate effect of adding ppm levels of sulfur results in roughly a doubling of the anode resistance. If the Ni particles were completely passivated a 7 -fold increase in the anode resistance would be expected according to the symmetrical cell data of Figure 5. Thus, $\mathrm{Ni}$ is indeed very much catalytically active despite the passivation of sulfur at very high Ni surface coverages. Schubert et al. ${ }^{4}$ studied and compared directly 1-cell stacks with Ni:YSZ and Ni:GDC cermet anodes respectively. The stack with Ni:YSZ anode showed the best performance. Despite this the stack with Ni:GDC anode showed significantly better tolerance toward sulfur poisoning both in terms 


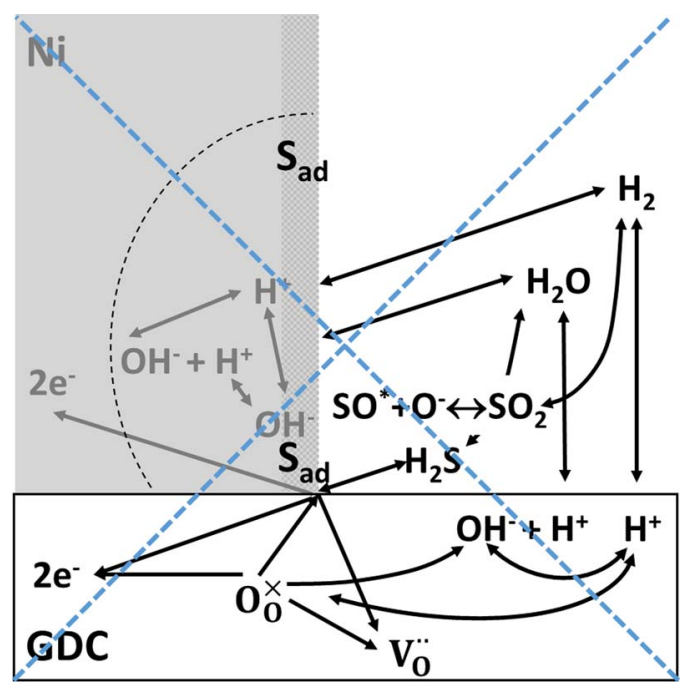

Figure 10. Proposed electrochemical processes in an Ni:GDC anode upon sulfur poisoning in Ref. 4, where the role of GDC is to extent the three-phaseboundary electrochemical reaction zone and thereby enhance the tolerance toward sulfur poisoning. The proposed cause to a higher S-tolerance of Ni:GDC based anodes cannot be true as the $\mathrm{H}_{2}$ oxidation reaction is despite sulfur poisoning still predominately catalyzed by $\mathrm{Ni}$.

of a lower relative voltage drop ( $1^{\text {st }}$ effect) and in terms of durability $\left(2^{\text {nd }}\right.$ stage effect). From these results, the present study and remaining literature results, it seems clear, that the positive effect of GDC on sulfur poisoning is real. However, it remains difficult to quantify the positive effect of having Ceria or Gadolinium doped Ceria present. Furthermore, it is also difficult to determine whether a Ni and GDC nanostructuring has any additional enhancement on the sulfur tolerance. In an attempt at explaining the positive sulfur tolerance effect of having GDC present Schubert et al. ${ }^{4}$ proposed that the effect of the electronic conducting GDC is to be electrocatalytically active and thereby extent the electrochemical reaction zone as sketched in Figure 10. However, this explanation is not supported by the present results as $\mathrm{Ni}$ is still supplying the by far predominant electrocatalytic activity despite the sulfur poisoning as concluded earlier. Furthermore, the concept can also not explain why the infiltration of isolated nanosized Ceria and/ doped Ceria and other particles also seem to enhance the sulfur tolerance. ${ }^{1}$ The reason for Ni being electrochemically very active despite the very high sulfur coverages $\theta_{S}>0.9$ is unclear. One possible explanation is that different surface sites are at play. It is e.g. well known that active sites for internal steam reforming are different from those which are electrochemically active. ${ }^{36}$ Furthermore, the sulfur has a tendency to adsorb and cluster in islands ${ }^{33,37-39}$ and it is presumably the reason why a Temkin-like isotherm applies, where the adsorption enthalpy varies linearly with coverage. It could be that the sites, which are very electrochemically active, are the last to be covered by sulfur. However, this remains speculation and it is clear that further systematic fundamental studies are needed to understand these mechanistic questions.

Effect of current on sulfur poisoning.-The Ni/YSZ data in Figure 9 are at OCV conditions, whereas the results of the present study are at a current load of $0.25 \mathrm{Acm}^{-2}$. In some studies current is speculated to have a beneficial effect on sulfur poisoning, where the flow of oxide ions may react with adsorbed sulfur and form $\mathrm{SO}_{2}$. However, no clear experimental evidence exists for such a mechanism to be of significant influence. In fact experiments have indicated that there is no substantial effect of current. ${ }^{40}$ Similarly, if a clear effect of current on sulfur poisoning was present one would expect an activating nature with a decrease in resistance as the current density is increased during recording of polarization-current characteristics in $\mathrm{H}_{2} \mathrm{~S}$ containing $20 \%$ humidified hydrogen fuel. However, we have not
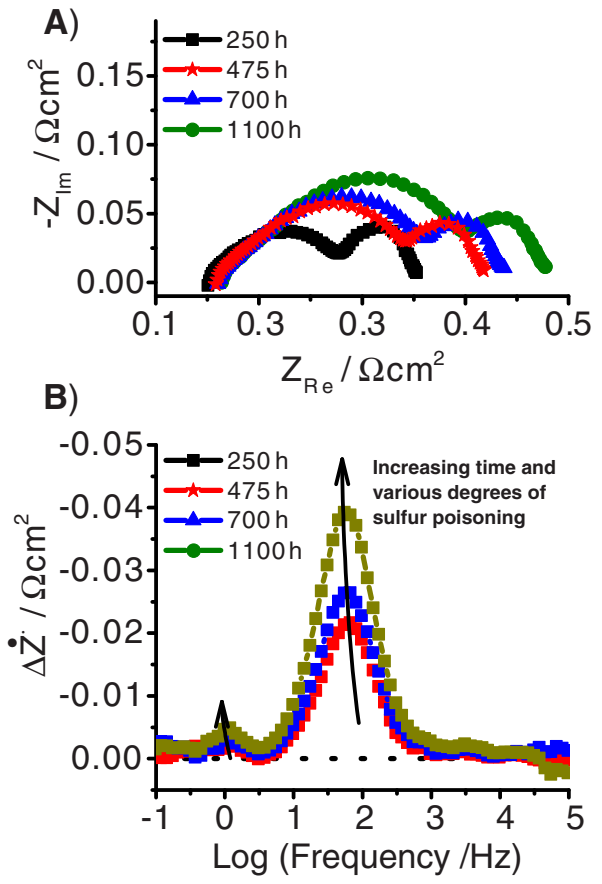

Figure 11. A) The EIS spectra after stopping $\mathrm{H}_{2} \mathrm{~S}$ exposure presented in figure 6 showing the degradation as a result of having been exposed to $\mathrm{H}_{2} \mathrm{~S}$ poisoning for increasing periods of time. B) The ADIS representation of the EIS changes.

observed such activation even at high current densities of $1-2 \mathrm{Acm}^{-2}$. The polarization-current characteristics remain linear. For these reasons, the comparison in Figure 9 seems reasonable.

Effect of sulfur on long term durability.-Impedance was recorded before and after each step with $\mathrm{H}_{2} \mathrm{~S}$ poisoning in Figure 6 in order to evaluate the long-term poisoning effect. This is shown in Figure 11 along with the ADIS visualization of the EIS changes. From Figure $11 \mathrm{~B}$ it is clear that the changes occur in the same frequency ranges as observed in Figure 7, which means, that it primarily is the anode that degrades and that an increase in the gas diffusion/conversion takes place. The change in the gas diffusion/conversion resistance is most likely due to a change in the cell current distribution as also discussed earlier, which presumably is an effect of an uneven degradation of the cell anode. This results in a more uneven current distribution, which increases the gas diffusion/conversion resistance.

From Figure 12 the change of the serial resistance $R_{s}$ and the polarization resistance $R_{p}$ during the testing in Figure 6 is shown. Only the polarization resistance is affected by the sulfur poisoning. Each segment of sulfur poisoning results in a degradation of the polarization resistance. In contrast, a close inspection of the serial resistance reveals a tiny steady increase, which is completely unaffected by $\mathrm{H}_{2} \mathrm{~S}$ addition and removal. The tiny steady increase of the serial resistance is presumable due to corrosion of the metal.

\section{Conclusions}

The performance of two metal supported solid oxide fuel cells (active area $16 \mathrm{~cm}^{2}$ ) with novel nanostructured Ni:GDC infiltrated anodes, but different anode and support microstructures were reported. The cell with the highest porosity showed the best performance on single cell level reported within the literature with fuel utilization corrected area specific resistance $\left(\mathrm{ASR}_{\text {corr }}\right)$ of $0.35 \Omega \mathrm{cm}^{2}$ at $650^{\circ} \mathrm{C}$. The sulfur tolerance of this novel nanostructured Ni:GDC infiltrated anode was studied and compared with the conventional SOFC Ni/YSZ cermet anode. From the testing and subsequent comparison it can be concluded that the nanostructured Ni:GDC infiltrated anode is significantly more tolerant toward sulfur poisoning compared to the 


\section{A) Cell $A$}

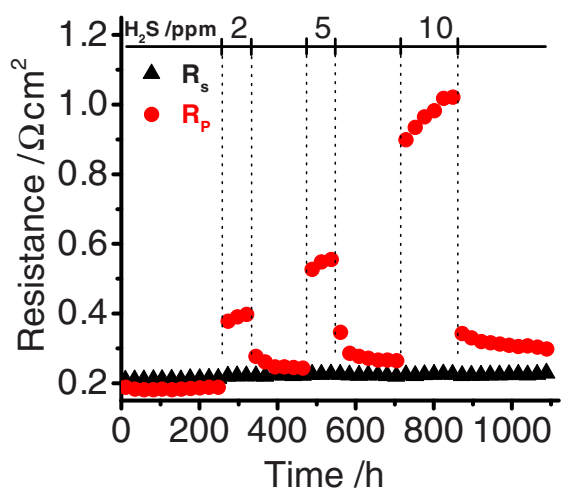

\section{B) Cell $B$}

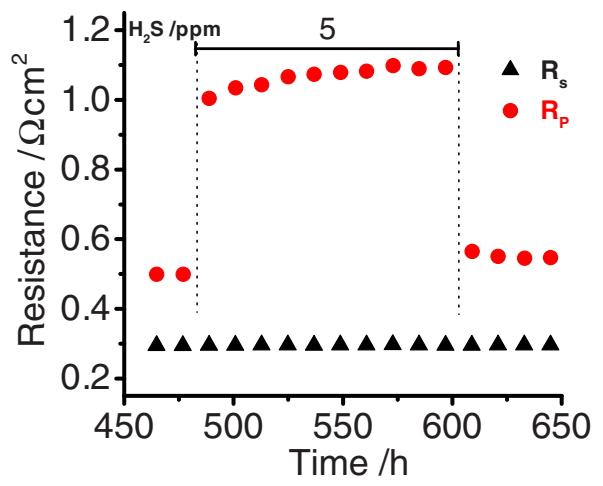

Figure 12. The effect of the $\mathrm{H}_{2} \mathrm{~S}$ sulfur poisoning on the serial resistance $\mathrm{R}_{\mathrm{s}}$ and the polarization resistance $R_{p}$ of tested cell A and B (see Figure 6).

conventional SOFC Ni/YSZ cermet anode. From the results it is clear that the $\mathrm{Ni}$ is still very much electrocatalytically active despite the very high sulfur Ni surface coverages upon sulfur poisoning. From these results it could also be excluded that the role GDC with respect to enhanced sulfur tolerance is not due to an extension of the three-phaseboundary reaction zone as speculated within the literature. Longterm degradation of the nanostructured Ni:GDC MS-SOFC anode as a result of the sulfur poisoning was observed. This has also under certain experimental conditions been reported for the Ni/YSZ cermet anode. The degradation under $\mathrm{H}_{2} \mathrm{~S}$ exposure was solely ascribed to the anode polarization resistance, whereas the serial resistance remained unaffected.

\section{Acknowledgment}

Financial support by the EU project METSAPP (FP7-278257), The Danish National Advanced Technology Foundation, and Energinet.dk under the project ForskEL 2012-1-10806 is gratefully acknowledged.

\section{References}

1. K. Sasaki, K. Susuki, A. Iyoshi, M. Uchimura, H. Kusaba, Y. Teraoka, H. Fuchino, K. Tsujimoto, Y. Uchida, and N. Jingo, J. Electrochem. Soc., 153, A2023 (2006).

2. L. Zhang, S. P. Jiang, H. Q. He, X. Chen, J. Ma, and X. C. Song, International Journal of Hydrogen Energy, 35, 12359 (2010).

3. H. He, R. J. Gorte, and J. M. Vohs, Electrochem. Solid-State Lett., 8, A279 (2005).

4. S. K. Schubert, M. Kusnezoff, A. Michaelis, and S. I. Bredikhin, J. Power Sources, 217, 364 (2012).

5. P. Blennow, J. Hjelm, T. Klemens $\emptyset$, A. H. Persson, S. Ramousse, and M. Mogensen, Fuel Cells, 11, 661 (2011).

6. J. Nielsen, T. Klemens $\varnothing$, and P. Blennow, J. Power Sources, 219, 305 (2012).

7. T. Klemensø, J. Nielsen, P. Blennow, ̊̊. H. Persson, T. Stegk, B. H. Christensen, and S. Sønderby, J. Power Sources, 196, 9459 (2011).

8. P. Blennow, J. Hjelm, T. Klemens $\varnothing$, S. Ramousse, A. Kromp, A. Leonide, and A. Weber, J. Power Sources, 196, 7117 (2011).

9. T. Ramos, K. Thydén, and M. Mogensen, ECS Trans. 28, 123 (2010).

10. M. Mogensen and P. V Hendriksen, in High Temperature Solid Oxide Fuel Cells: Fundamentals, Design, and Applications, S. C. Singhal and K. Kendall, Editors, p. 261, Elsevier Advanced Technology, Oxford (2003).

11. S. H. Jensen, J. Hjelm, A. Hagen, and M. Mogensen, in Handbook of fuel cells: Advances in Electrocatalysis, Materials, Diagnostics and Durability, W. Vielstich, H. Yokokawa, and H. A. Gasteiger, Editors, Vol. 5-6, chapter 53, John Wiley \& Sons, (2009).

12. G. Reiss, H. L. Frandsen, W. Brandstätter, and A. Weber, J. Power Sources, 273, 1006 (2015)

13. H. Iwaia, N. Shikazonob, T. Matsuic, H. Teshimab, M. Kishimotoa, R. Kishidac, D. Hayashia, K. Matsuzakib, D. Kannob, M. Saitoa, H. Muroyamac, K. Eguchic, and N. Kasagib, J. Power Sources, 195, 955 (2010).

14. S. Gewiesz and W. G. Bessler, J. Electrochem. Soc, 155, B937 (2008).

15. A. E. Richards, M. G. McNeeley, R. J. Kee, and N. P. Sullivan, J. Power Sources, 196, 10010 (2011)

16. N. Epstein, Chem. Eng. Sci., 44, 777 (1989).

17. J. Nielsen, T. Jacobsen, and M. Wandel, Electrochimica Acta, 56, 7963 (2011)

18. J. Nielsen and J. Hjelm, Electrochimica Acta, 115, 31 (2014).

19. P. Hjalmarsson and M. Mogensen, Journal of Power Sources, 196, 7237 (2011).

20. V. Sonn, A. Leonide, and E. Ivers-Tiffée, J. Electrochem. Soc., 155, B675 (2008).

21. T. Ramos, M. Søgaard, and M. B. Mogensen, J. Electrochem. Soc., 161, F434 (2014).

22. A. Lasia, in Modeling and Numerical Simulations, Modern Aspects of Electrochemistry., p. 67, Springer New York (2009).

23. J. Bisquert et al., Electrochemistry Communications, 2, 601 (2000)

24. W. J. Albery and A. R. Mount, Journal of the Chemical Society, Faraday Transactions, 90, 1115 (1994).

25. Z. Cheng, J. H. Wang, Y. Choi, L. Yang, M. C. Lin, and M. Liu, Energy \& Environmental Science, 4, 4380 (2011).

26. J. F. B. Rasmussen and A. Hagen, J. Power Sources, 191, 534 (2009)

27. M. Gong, X. Liu, J. Trembly, and C. Johnson, J. Power Sources, 168, 289 (2007).

28. C. Xu, P. Gansor, J. W. Zondlo, K. Sabolsky, and E. M. Sabolsky, J. Electrochem. Soc., 158, B1405 (2011).

29. A. Hagen, J. Electrochem. Soc., 160, F111 (2013).

30. J. B. Hansen, Solid-State Lett., 11, B178 (2008).

31. D. Papurello et al., Chemical Engineering Journal, 283, 1224 (2016).

32. A. Kromp, J. Nielsen, P. Blennow, T. Klemens $\varnothing$, and A. Weber, Fuel Cells, 13, 598 (2013).

33. J. Bøgild Hansen and J. Rostrup-Nielsen, in Handbook of fuel cells: Advances in Electrocatalysis, Materials, Diagnostics and Durability, W. Vielstich, H. Yokokawa, and H. A. Gasteiger, Editors, Vol. 6, chapter 65, John Wiley \& Sons, (2009).

34. S. Zha, Z. Cheng, and M. Liu, J. Electrochem. Soc., 154, B201 (2007).

35. Y. Matsuzaki and I. Yasuda, Solid State Ionics, 132, 261 (2000).

36. J. R. Rostrup-Nielsen, J. B. Hansen, S. Helveg, N. Christiansen, and A. K. Jannasch, Appl. Phys. A, 85, 427 (2006).

37. L. Ruan, F. Besenbacher, I. Stensgaard, and E. Laegsgaard, Phys. Rev. Lett., 70, 4079 (1993).

38. F. Besenbacher, I. Stensgaard, L. Ruan, J. K. Nørskov, and K. W. Jacobsen, Surface Science, 272, 334 (1992)

39. J. V. Lauritsen, R. T. Vang, and F. Besenbacher, Catalysis Today, 111, 34 (2006).

40. A. Hagen, G. B. Johnson, and P. Hjalmarsson, J. Power Sources, 272, 776 (2014). 